\title{
Improved Understanding Of Greenwashing And Green Consumer with Rasch Model Analysis
}

\author{
Yulia Hamdaini Putri* \\ Management, Economic, Sriwijaya University \\ Palembang, Indonesia \\ Submitted Date : \\ yuliahamdaini@unsri.ac.id \\ 3 September 2021 \\ Aslamia Rosa \\ Accepted Date : \\ 29 November 2021
Management, Economic, Sriwijaya University
Palembang, Indonesia
aslamiarosa@unsri.ac.id \\ Hera Febria Mavilinda \\ Management, Economic, Sriwijaya University \\ Palembang, Indonesia \\ herafebria@fe.unsri.ac.id
}

\section{Suggested Citation:}

Chang, K. C., Hsu, C. L., Hsu, Y. T., \& Chen, M. C. (2019). How green marketing, perceived motives and incentives influence behavioral intentions. Journal of Retailing and Consumer Services, 49(April), 336-345. https://doi.org/10.1016/i.jretconser.2019.04.012

\section{Abstract:}

As extensive information comes so fast, increasing consumer awareness of greening the environment increases. Environmental damage caused by human waste, natural disasters, and non-renewable natural resources, and damage to natural ecosystems makes consumers careful in purchasing decisions. This study aims to know indicators in the greenwashing and green consumers which one the least liked or preferred based on the gender of generation Z. Method of analysis is using the Rasch model. A sample of 340 respondents generation $Z$. The result is green consumers (consumers throw garbage in their place, water-saving consumers, consumers like cleanliness). Consumers are willing to pay more to get the product labelled eco-product/go green. This study is limited to explaining the response of generation Z regarding the items contained in the greenwashing and green consumer variables.

Keywords: Generation-Z; Green Consumer; Green Marketing; Greenwashing

JEL Classification: M31

*Corresponding Author 


\section{Research Background}

Generation $Z$ is very good at using technology and the internet at their fingertips. They get fast and up-to-date information on anything they want to look for, including searching for information about using a product or exploring a place. Generation Z will look for product information about the manufacturing process, packaging, benefits, attributes attached to a work. Generation $Z$ will also choose tourist attractions/hospitals/hotels by looking for references via the internet, such as convenience, security, and ease of access (Arta \& Purnami, 2018; Punitha \& Mohd Rasdi, 2013).

As extensive information comes so fast, the increase of consumer awareness on greening the environment is improving. Environmental damage caused by human waste, natural disasters, non-renewable natural resources, and damage to natural ecosystems makes consumers cautious in purchasing decisions. Increasing public concern for the environment encourages them to become environmentally responsible consumers and switch to using environmentally-based products (Rahayu, Abdillah, \& Mawardi, 2017); greening the future climate can create a sustainable life for the future generations. (Chae \& Ko, 2016)

Companies compete for the inexperienced client marketplace segment. The green client is growing client consciousness of environmental problems. Consumers choose, use, recommend, and buy a product, beginning from packaging, production processes, perceived blessings or provider products-for example, hotels, hospitals, traveller attractions. Green corporations commonly have an inexperienced cross-brand and a positioning region a tremendous influence on the minds of consumers.

A simple advertising approach is carried out to reply to demanding situations approximately environmental problems that arise today. Green advertising stated designing, promoting, figuring out prices, and dispensing merchandise for ecological sustainability ((Murin, Marková, Zelený, \& Jad'ud'ová, 2015; Polonsky, 2011). Products are known as eco-merchandise, natural merchandise. Merchandise that might be effortlessly recycled by marking the diploma of ease. The product decomposes (marked with a triangle or variety symbol), nonpoisonous product (no longer harm the ecosystem), water-saving, electricity-saving, gas-saving merchandise, inexperienced-labelled product. (Simão \& Lisboa, 2017)

In Indonesia, one of the successful brands in the environmentally friendly market segment is The Body Shop as the market leader for the go green cosmetic brand. This company claims that its products do not use animals as experimental materials. For babies and toddlers' needs, baby diaper products that carry Go green Merries, produced by Kao, claim that the remaining used baby diapers will be recycled into other household items to don't damage the environment. A supplier of environmentally friendly food and beverage packaging specifically for the Bali area, Affinity Supply Co., claims that the products produced are readily biodegradable by nature. This company collaborates with restaurants and hotels. Suzuki car company participates in Corporate Social Responsibility regarding fuel-efficient cars and developing Smart Hybrid Vehicle by Suzuki technology as a bridge to electric vehicles. Other competing companies then follow them. The green consumer segment is willing to pay a premium price to get products labelled as environmentally friendly or use ecologically friendly service products to create a sense of security and satisfaction.

However, not all products that use a green marketing strategy are environmentally friendly. The company commits unethical acts by committing fraud in marketing communications, from now on known as greenwashing. Several previous research findings stated that if greenwashing increases, the product's increased risk perception can reduce the level of consumer satisfaction with the product (Martínez et al., 2020). Marketing communications that are not accompanied by good company performance with attention to greening the environment make the company impression that it will be worse than no advertising about going green (Nyilasy, Gangadharbatla, \& Paladino, 2014)

Products labelled as environmentally friendly must pass the AMDAL (Environmental Impact Analysis) process and be issued a go green (environmentally friendly), ecolabel, eco-product certification. Products labelled as eco-friendly may also require several trials before they are declared eligible. However, not many consumers understand this certification process. Consumers believe more through advertising (green advertising) that is carried than to study in-depth. (Chen, 2016)

Several studies have shown that green marketing positively affects purchasing behaviour and intention (Arta \& Purnami, 2018; Rini, Sukaatmadja, \& Giantari, 2017; Widyastuti, 2019). Research on green advertising as part of green marketing affects the brand image of the product and company(Chen, 2016; Nyilasy et al., 2014; Walker \& Wan, 2012). However, previous studies have not discussed the statement items that describe which indicators in the greenwashing and green consumer variables are the least liked or preferred based on the gender of generation $Z$. 
The notion of environmental marketing science, starting with Leigh et al. in 1988, ecological product positioning research should be an essential consideration in consumer marketing. This research also dealt with an extensive theory of consumer behaviour Ajzen in 1980. (Fisk, Grove, Kangun, \& Pickett, 1996). Green marketing is a strategic effort to create a business based on environment and health has been known in the late 1980s and early 1990s. Green marketing appears as public awareness of a healthy and safe environment from sustainable environmental damage in the future. There are several definitions of green marketing based on previous research including: marketers carry out marketing strategy efforts by raising ecological issues in increasing the existence of enviro-labels (environmentally friendly labels) and ensuring the presence of ecoproducts (Murin et al., 2015); Green marketing is defined as "the efforts of a company to design, promote, price, and distribute products in a way that promotes environmental protection." (Polonsky, 2011); Green marketing is a concept that describes the implementation of a marketing program aimed at environmentally conscious market segments (Majerova, 2015); Do Paco et al said that as a corporate social responsibility, green marketing refers to "a holistic management process that is responsible for identifying, anticipating and satisfying the needs of customers and society, in a profitable and sustainable manner" (Chae \& Ko, 2016); Green Marketing is a marketing process that has all the capabilities to increase the economic sense of a business without noticeably increasing its brand image as green. Apart from being a visual recognition, a brand is also related to consumers' intuitive feelings about a service or product (Punitha \& Mohd Rasdi, 2013); Welford defines green marketing as a management process that is responsible for identifying, anticipating and meeting customer and community requirements in a profitable and sustainable manner (Chan, 2013); Green marketing is an approach that shows signs of shifting consumer attention to environmentally friendly products (Cherian \& Jacob, 2012). From some of these definitions regarding Green Marketing (environmentally friendly marketing), it can be concluded that the efforts of marketers to design, promote, determine prices, and distribute products by paying attention to sustainability and greening the environment in the long term.

There are 4 indicators of green marketing. They are green products, green price, green place, and green promotion. Entrepreneurs wishing to use the green marketing concept came up with: a). Identify the customer's environmental needs and develop products to address those needs; b). Developing environmentally responsible products; c) has a lower impact on the environment than its competitors. Various products on the market support green marketing, including a) Products are made from recycled materials; b) Products that can be recycled or reused; c) Efficient products that save water, energy or gasoline, save money, and reduce the environment's impact; d) Products with environmentally friendly packaging; e) Products with a green label; f) Organic products; g) A service that provides rental or loan services; $h$ ) A product certificate that meets or ensures that the product meets or exceeds the criteria for being environmentally responsible.

Green price is an essential element of the marketing mix; most customers are prepared to pay more if the additional product is perceived value. This value can enhance performance, function, design, visual appeal, or taste. Environmental benefits are usually a bonus but will often determine between the product's value and quality with competitors'. Most green products' prices require extra costs incurred by consumers as quality and environmentally friendly products.

For green places, choosing where and when to make the product significantly impacts customers to become interested. Only a few customers are interested in purchasing green products. The location must also match the image that the company wants. The company's area must differentiate the company from competing companies; this can be done by in-store promotions and visually appealing displays or using recycled materials to emphasize environmental and other benefits.

Promote products and services to target markets, including advertising, public relations, sales promotion, direct marketing, and on-site promotion. Savvy green marketers will strengthen environmental credibility by using sustainable marketing and communication tools and practices. The key to the success of green marketing is credibility.

Contrary to green marketing. The term greenwashing is used by companies or marketers who use the concept of environmentally friendly marketing but do not use the actual benefits ethically. Some definitions of greenwashing are as follows: Green-washing is a marketing communication that raises environmental, social issues, but in fact, the products offered are not environmentally friendly (Lim, Ting, Bonaventure, Sendiawan, \& Tanusina, 2013); Green-washing is a term for advertising and labels that promises more 
environmental benefits than it produces but is still dubious (Dahl, 2010); Green-washing, also known as ecowhitening, white-wash, eco-wash, eco-bleaching, green sheen or green image washing, is a form of advertising where green marketing is not practised (Pires et al., 2019); Green-washing is defined as intentionally misleading or deceiving consumers with false claims about the company's environmental impact and practices (Nyilasy, Gangadharbatla, and Paladino 2014); Green-washing is a company that knowingly misleads or defrauds customers with false claims about their actions and environmental impacts to improve public reputation or further build a favourable public image (Zhang, Li, Cao, \& Huang, 2018)

Furthermore, Zhang et al. developed five indicators to measure the perception of greenwashing from a consumer perspective, namely: (1) product is misleading with words about its environmental features (2) misleading products with visuals or graphics regarding environmental features; (3) work is associated with vague or seemingly unprovable green claims; (4) the product exaggerates or exaggerates what green does; (5) products leave out or cover up important information, making green claims sound better than that.

Meanwhile, according to previous research (Nyilasy, Gangadharbatla, and Paladino 2014), greenwashing is a consumer reaction to a situation where green advertising messages and real corporate social responsibility (CSR) interact. Thus the greenwashing indicator can be divided into 2: green advertising (communication and environmental performance) and Corporate Social Responsibility (CSR).

TerraChoice Environmental Marketing categorized marketing claims into the "seven sins of greenwashing" (Dahl, 2010) to value thousands of products in the United States and Canada. The sin of hidden trade-offs: made by suggesting a product is "green" based on a narrow set of attributes. That makes no sense without paying attention to other critical environmental concerns (e.g., paper produced from sustainably harvested forests may still generate energy and costs significant pollution). The sin without evidence is committed by ecological claims that cannot be substantiated by accessible supporting information or reliable third-party certification (e.g., paper products claiming varying percentages of post-consumer recycled content without proof). The sin of obscurity is committed by any claim so poorly defined or broad that its real meaning is likely to be misunderstood by consumers (e.g., "Natural"). Irrelevant sin: committed by making environmental claims that may be true but insignificant or unhelpful to consumers looking for environmentally friendly products (e.g., "CFC free" is meaningless given that chlorofluorocarbons are banned by law). Sins less than two crimes: committed by claims that may be true in the product category, but the risk of distracting consumers from health or environmental impacts is greater than the type as a whole (e.g., organic cigarettes). The sin of fibbing: committed by filing a completely false environmental claim (e.g., a product falsely claiming to be Energy Star certified). The sin of fake labelling: committed by exploiting consumer demand for third party certification with counterfeit labels or third party support claims (e.g., images such as certification with green jargon such as "environmentally friendly")

Green Consumer or consumer care for the environment is a term for increasing consumer awareness of environmental problems. In choosing, using, recommending and purchasing a product, from packaging, manufacturing processes, perceived benefits or service products such as hotels, hospitals, etc., tourist attractions and later. Several definitions of the green consumer have been widely discussed in previous studies, including Environmentally friendly consumers are consumers who prefer products that are less likely to endanger human health or damage the environment (Zhu \& Sarkis, 2016); Green Consumer is Consumers increasingly aware of pressing environmental problems in a fast-growing global economy (Lai and Cheng 2016); Green Consumer is a consumer who is mindful of the responsibility for environmental protection and environmental regulations (Chang, Hsu, Hsu, \& Chen, 2019)

The three distinctive statements of green consumers are, first, "I identify myself as someone who cares about 'green/environmental issues,' second "I purchase and consume green products," and third, "I consider my lifestyle to be' green. "(Zhu \& Sarkis, 2016)

Overall, green marketing and consumerism are still relatively young, and research on green marketing in China is even more emerging. The study focuses only on green issues in China. This research on green marketing has proposed "4Rs" (Transfer of customer needs, Reconsumption, Reorientation of the marketing mix, Reorganization); However, minimal research has been conducted on China using the 4R perspective. (Zhu and Sarkis 2016) Green marketing research in Hong Kong uses a measurement tool for consumer perceptions, attitudes, problems, responsibilities, expectations, and habits. To further convince consumers to consume green products, packaging and advertising strategies should emphasize individuals' positive effects on specific environmental issues if green products are purchased to change consumers' attitudes and feelings of responsibility towards the environment. (Lai \& Cheng, 2016)

Previous research also studied several cooperative contracts in green product supply chains and investigated their environmental performance. This problem is analyzed and modelled in three agreements to 
increase cooperation: price only, green marketing cost-sharing, and a two-part tariff contract. The analysis results show that collaboration among partners can help supply chains achieve environmental improvements. (Hong \& Guo, 2019)

Another research finding, energy provider communication, appears to align with academic research on potential customer benefits (practical benefits, "warm light," natural experiences). However, detailed information about the impact of consumer decisions can improve communication. Besides, providers can increase their visual messages' effectiveness by using more images related to renewable energy. (Herbes \& Ramme, 2014). Christian Fuentes stated that green products are marketed not only through practice but also as enabling practitioners, that is, tools in the fulfilment of ways that are problematic to the environment (Fuentes, 2015).

Pires et al. stated that greenwashing confuses and influences consumers' trust in green products in retail. After implementing the system, it is concluded that the results are feasible. Using fuzzy logic can help analyze and determine consumer satisfaction levels and help companies make future estimates of consumer behaviour from green products (Pires et al., 2019). Other research shows that today, consumers purchase green products based on organizations' green claims, where many consumers remain confused and unsure about their authenticity. The aftereffect is when consumers become aware of the existence of greenwashing points towards distrust, more prudent purchasing behaviour in the future, and spread their presence to other consumers through word of mouth (Lim et al., 2013)

Nyilasy et al.'s research shows that the negative effect of low firm performance on brand attitude is more substantial in the presence of green advertising compared to general company advertising and no advertising. Furthermore, when the company's environmental performance is high, green advertising and public company produce a more unfavourable brand attitude than no advertising. (Nyilasy, Gangadharbatla, and Paladino 2014)

Ecolabel has emerged as one of the main tools of green marketing. Green marketing can learn from conventional marketing in finding ways other than labeling to promote eco-friendly products. Examples include addressing a wider range of consumers, working with positioning, pricing and promotion strategies and being actively involved in market creation. (Rex \& Baumann, 2007). The right commitment of resources is critical to the success of any green initiative. The study also supports the idea that being the first company in the industry to initiate a green program provides few tangible benefits (Richey et al. 2014).

Substantive actions on environmental issues (green roads) do not harm or benefit the company financially, but symbolic actions (green talk) are negatively related to financial performance. Green-washing (the difference between green talk and green walk) harms financial performance, and green-highlighting (the concentrated effort of dialogue and hike) does not affect economic performance (Walker \& Wan, 2012).

Increasing awareness about various environmental issues has led to a shift in the way consumers live people's lives. There has been a change in consumer attitudes towards a green lifestyle. People are actively trying to reduce their impact on the environment. However, it is not widespread and is still developing. This study introduces green marketing and looks into how different consumer attributes are related to the idea of green marketing (Cherian \& Jacob, 2012). Eco-labelling in the food industry is focused solely on promoting organic farming, limiting the scope to the agricultural stage of the supply chain. Carbon labelling informs about the carbon footprint over the product life cycle. (Barbulescu, 2017)

Ad design with self-referencing and strong arguments has the best advertising effect; positive moral and social emotions have a better advertising effect. Under the action of emotion, subject preferences for ad design will also change. This research helps construct and optimize green advertising designs to understand the relationship between the factors influencing the advertising effect and green marketing benefits. (Kao \& Du, 2020). Consumers develop positive green marketing awareness based on evolving environmental knowledge. They become aware of a retail store's eco-marketing program when they notice that it allocates a particular space to sell eco-friendly products (Suki, Suki, \& Azman, 2016).

\section{Research Method}

The population of generation Z in South Sumatra. Based on the initial observations, many people in South Sumatra doubted the green marketing concept promoted by several companies. South Sumatra became the chosen place to conduct research. The sample uses the Lemeshow formula, with a selection of 340 respondents. This research is quantitative. Rasch modelling was initially being used in education to determine individual 
academic abilities. Over time this modelling was applied in other fields of science. The data were collected through a questionnaire. Then the data were analyzed using the Rasch model-assisted. The Rasch model converts the item scores measured on a Likert rating scale (which are ordinal data) into interval scales called "logarithmic probability units" (logits). If the instrument meets at least one of the above criteria, the instrument item is suitable for use. The validity test concludes that all greenwashing and green consumer items have statistical fit measures so that the instrument can be used for research. Rasch modelling overcomes data integrability by accommodating logit transformations by applying logarithms to the odds ratio of the respondents' raw data. This study's univariate analysis shows statement items that describe which indicators in the greenwashing and green consumer variables are the least liked or preferred based on the gender of generation Z seen from the Wright map items' distribution people (characteristics) generated from the Rasch Modeling. (Nguyen and Ng 2014; Sari et al. 2016; Setiawan, Panduwangi, and Sumintono 2018)

\section{Result}

The questionnaire was distributed online so that the generation Z category respondents born from 1995 to 2010 exceeded the target, namely 340 respondents. Respondent profiles are described in the following table

Table 1 Respondent Profiles

\begin{tabular}{lcr}
\hline Information & Frequent & Percentage (\%) \\
Sex & & \\
Male & 119 & 35 \\
Female & 221 & 65 \\
Statue & & \\
Single & 340 & 100 \\
Job & & \\
College Student & 338 & 94.2 \\
Student & 2 & 0.6 \\
Age & & \\
Under 25 years & 340 & 100 \\
Monthly expenses & & \\
Under 1 million rupiah & 233 & 68.5 \\
1-2 million rupiah & 94 & 27.6 \\
2-5 million rupiah & 12 & 3.5 \\
5-10 million rupiah & 1 & 0.3 \\
\hline
\end{tabular}

Source: Data Processed (2020)

Table 1 explains that most respondents are women under 25 years of age and 221 respondents or 65 per cent of the total sample. These female respondents are students, with the most monthly expenses spending below 1 million rupiahs 156 respondents or 70 per cent of the total female respondents. Furthermore, 26 per cent (58 respondents) of female respondents spent around 1-2 million each month. 2 per cent (6 respondents) spent approximately 2-5 million. Only one female respondent stated that she spent more than 5 million rupiahs.

As many as 117 male respondents (98 per cent) were college students, 2 per cent were students. Seventy-seven or 65 per cent of male respondents spent less than 1 million rupiahs per month, 36 respondents or 30 per cent of male respondents spent around 1-2 million rupiahs per month, 6 ( 5 per cent) male respondents men spent approximately $2-5$ million rupiahs. It can be concluded that male respondents with the status of students spend the most money under 1 million rupiah per month.

The respondents' knowledge of eco-green product brands as a whole is quite diverse. On average, stainless steel or bamboo materials tend not to be branded or branded, but respondents cannot clearly remember the brand. Respondents know that this straw made of stainless steel or bamboo has replaced the plastic straw that has been used to anticipate future build-up of garbage.

Data analysis using the Rasch model tends to deepen each item statement in a questionnaire. Here's about the validity test: The level of validity of the response on items based on the value of Outfit Mean Square (MNSQ) received was $0.5<\mathrm{MNSQ}<1.5$, the Outfit Z-Standard (ZSTD) conformity of the received value of the $Z$ test $-2.0<$ ZSTD $<+2.0$, and Point Measure Correlation (Pt Mean Corr) $0.4<P t$ Mean Corr $<0.85$. Item Statistics MisFit Order regarding the validity test, it can be concluded that the questionnaire used is valid. 
Reliability test to measure overall that the questionnaire is suitable for use, it is known that the alpha value is more than $0.6<0.99$ so that it can be concluded that the questionnaire is ideal for use (table 2)

Table 2 Reliability Test

\begin{tabular}{lc}
\multicolumn{1}{c}{ Description } & Alpha Value \\
\hline Person Reliability & 0.79 \\
Item Reliability & 0.99 \\
\hline
\end{tabular}

Source: Data Processed (2020)

\section{Wright Map Analysis}

Table 3 classified the items according to their item logit scores (shown in Figure 2). The classification of items into six strata is done by dividing the items' logit score into six equal parts. Specifically, the stratification process uses percentile values of $16.67,33.33,50,66.6,7$, and 83.33 , respectively. Figure 2 is an item-person map. The left-hand side shows the respondents' distribution according to their logit scores, from the person who disagreed the most (logit score $1 / 4-3.63$ ) to the person who most agreed (logit score + 3.44). On the right side of the map is displayed the difficulty level of each item. Ranging from the easiest to agree on (logit score $1 / 4-1.12$ for Gc5 items) to the most difficult to agree on (logit score $1 / 4+0.72$ from gw2). These items function well and can separate each respondent, meaning that they have good discriminatory power.

Table 3. Classification of Items following the Respondent Item Logit Score

Category Criteria Item

More difficult to be considered

Difficult strata 1

Difficult strata II

Logit Value $\geqslant 0.7249$

$0.7249>$ LV $\geqslant 0.4234$

Difficult strata III

$0.4234>L V \geqslant 0.0100$
Gw 2 (visually misleading) LV 0.72

Gw 1 (misleading words) LV 0,60

Gc 9 (prefer to take transportation) LV 0,51

Gw7 (there is no CSR) LV $=0,48$

Gc 14 (consumers like to purchase bottled water) $\mathrm{LV}=0,48$

Gw3 (the green claim is not clear) $L V=0,48$

Gc12 (consumers are willing to purchase plastic bags) $\mathrm{LV}=0,47$

Gw4 (exaggerate product functionality)

$\mathrm{LV}=0,44$

Gc11 (consumers bring their own grocery

bags) $L V=0,39$

Gc 8 (consumers know the green product certificate) $L V=0,39$

Gw 5 (cover important information) LV

$=0,35$

Gw 9 (green claims do not match performance) $L V=0,34$

Gc 6 (consumers like to recycle unused objects) $L V=0,19$

Gc10 (loyal consumers with green

products) $L V=0,11$

Gw 6 (product green certificate is uncertain)

$\mathrm{LV}=0,05$

Gc4 (consumers pay attention to the green label) $\mathrm{LV}=0,04$ 


\begin{tabular}{|c|c|c|}
\hline Category & Criteria & Item \\
\hline $\begin{array}{l}\text { More comfortable to be } \\
\text { considered }\end{array}$ & & \\
\hline Difficulty Strata IV & $0.0100>L V \geqslant-0.2934$ & $\begin{array}{l}\text { Gc2 (consumers are willing to pay more) LV } \\
=-0.06 \\
\text { Gc1 (consumers purchase green products) } \\
\text { LV }=-0.10 \\
\text { GW8 (consumers are less aware of green } \\
\text { products) LV }=-0.72\end{array}$ \\
\hline Difficulty Strata V & $-0.2934>L V I \geqslant-0.7966$ & $\begin{array}{l}\text { Gc } 13 \text { (using own bottle of water) LV = - } \\
0,72\end{array}$ \\
\hline Difficulty Strata VI & $L V I<-0.7966$ & $\begin{array}{l}\text { Gc } 3 \text { (consumers throw garbage in their } \\
\text { place) LV }=0.72 \\
\text { Gc7 (water saving consumer) LV }=-1.62 \\
\text { Gc5 (consumers like cleanliness) LV }=- \\
1.90\end{array}$ \\
\hline
\end{tabular}

Source: Data Processed (2020)

Figure 1. Variable Maps

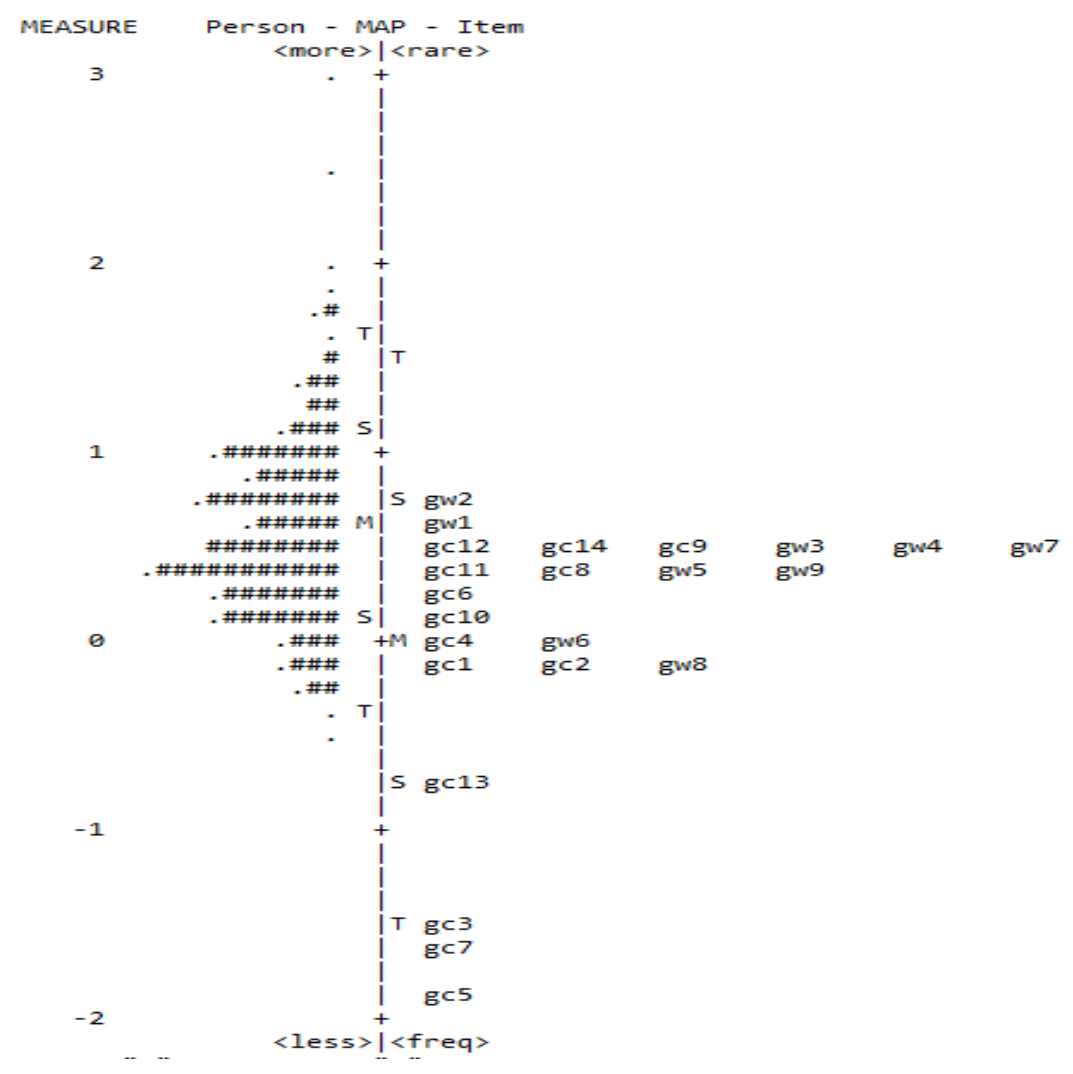

Source: Data Processed (2020)

The three separate groups of respondents are as follows (see figure 1): there are 163 people (47 per cent) who are very easy to consider; 158 people ( 47 per cent) thought it was enough; and 19 people (6 per cent) who are very difficult to consider nine greenwashing items and fourteen green consumer items. On the right side of the item-person map, it can be seen that GC 3 (consumers throw garbage in their place) LV $=0.72, \mathrm{Gc7}$ (consumers save water) LV $=-1.62, \mathrm{Gc5}$ (consumers like cleanliness) LV $=-1.90$ are items that are highly liked or considered by the majority of respondents in describing themselves as green consumers. Greenwashing item Gw 2 (misleading product with visual or graphic about its environmental features) $L V=0.72$, considered as the most difficult item to like in the greenwashing variable, the second item that is difficult to like is Gw misleading) LV 
0.60, Gw7 (no CSR) LV = 0.48, Gw3 (unclear green claim) LV = 0.48, Gw4 (exaggerate product functionality) LV $=0.44$.

Figure 2. Item Map Person

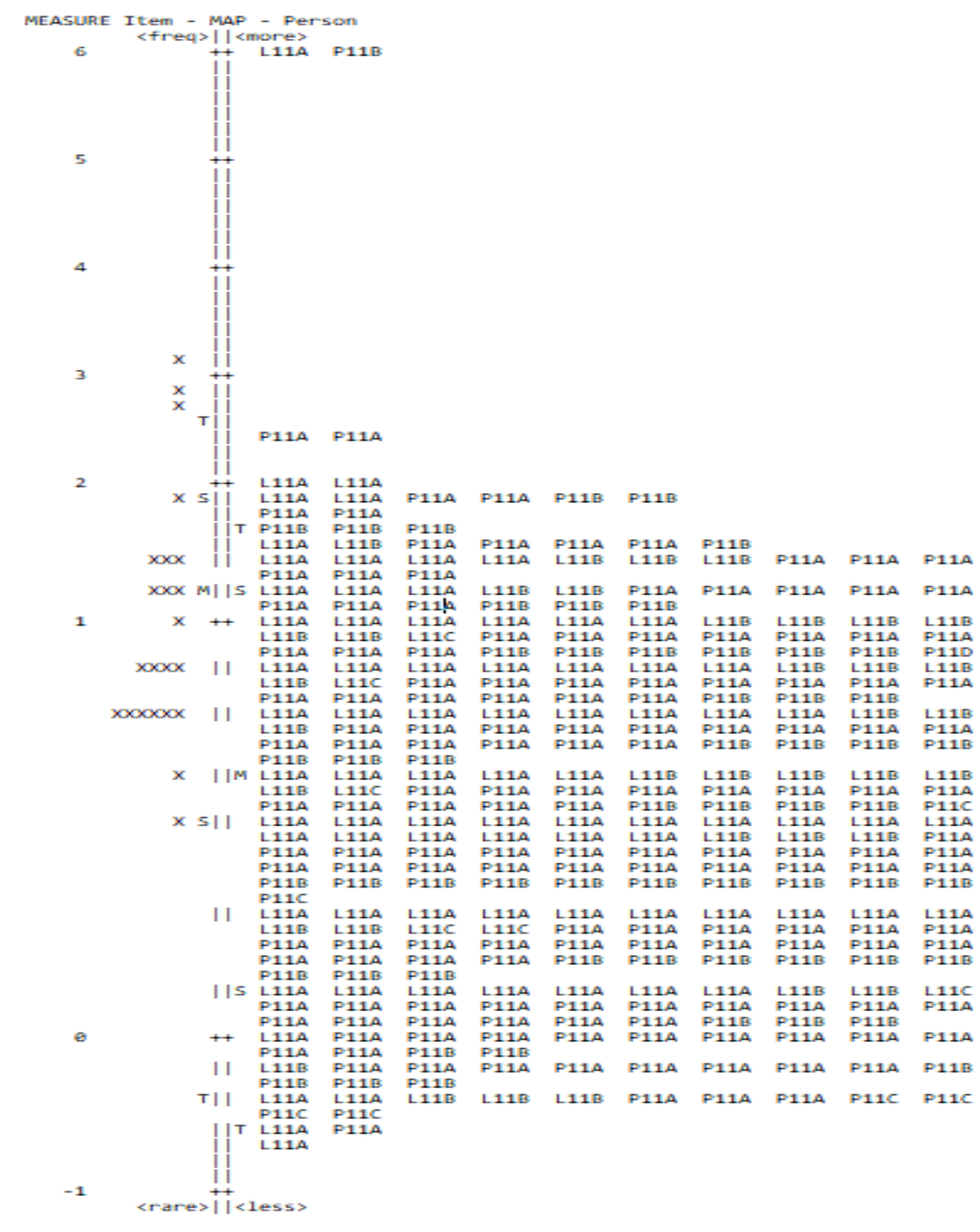

Source: Data Processed (2020)

Items from the green consumer variable that are least preferred start in the second-order, namely Gc 9 (prefer to take transportation) LV $0.51, \mathrm{Gc} 14$ (consumers like to purchase bottled water) LV $=0.48, \mathrm{Gc} 12$ (consumers are willing to buy plastic bags) $L V=0.47$. These items are considered not to reflect the identification of a consumer liking a green-labelled product.

Items of greenwashing are considered preferred and easy to answer by consumers. In the fourth difficulty order; namely, GW 8 (consumers do not know green products) LV = -0.72 GW 8 (Consumers do not know products labelled green / go green) $L V=-0.72$. Thus, it is necessary to increase green marketing communication to know about products tagged green / go green.

In Figure 3 and figure 4, we can see that male respondents, who are students, are not married and spend an average of less than 1 million per month. They most agree in considering the nine items of greenwashing and fourteen items of green consumers. In contrast, female respondents, with the status of a student, unmarried and 
spending an average of 1-2 million rupiahs per month, most agreed in considering the nine items of greenwashing and fourteen items of green consumer. Thus it is easier for women to spend their money purchasing go green products/products labelled green with considerations of more expenditure.

\section{DIF (Differential Item Functioning)}

The detection of bias on items in the Rasch model analysis is shown on the DIF . DIF is necessary to determine whether the items provided tend in confident respondents' categories. Figure 3 shows the types of respondents based on gender. Male respondents from 22 question items 9 question items did not contain bias. In comparison, the value of 13 items below 0.05 meant that they had a bias, female respondents from 22 question items only 6 items that did not contain bias, while 16 question items contained bias. It can be concluded that the response of men is different from that of women. Male respondents found it more difficult to answer questions than female respondents.

Figure 3. Person DIF Plot (Gender)

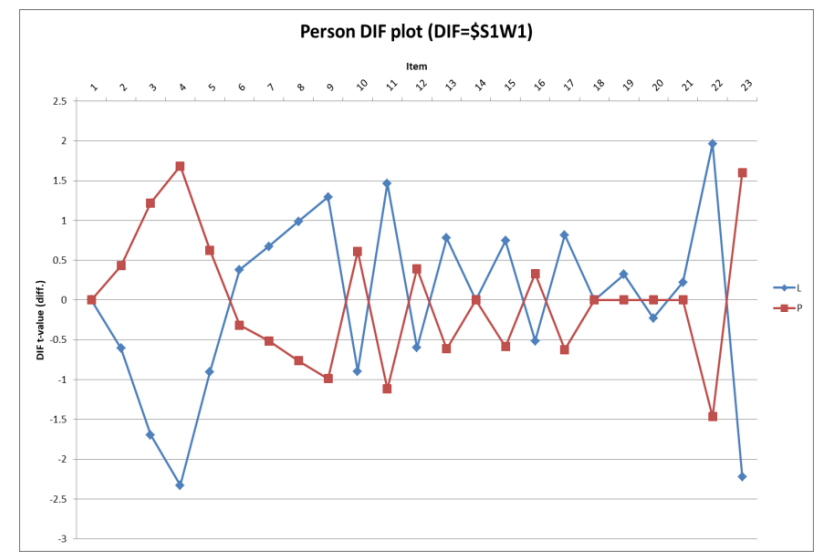

Source: Data Processed (2020)

Figure 3 shows the categories of respondents based on expenses. Respondents with expenditures below 1 million from 22 question items 9 question items did not contain bias, while the value of 13 items below 0.05 meant that they included bias, respondents with expenditures of 1-2 million from 22 question items only 8 items that did not contain bias, while 13 questions biased. Respondents spend 2-5 million from 22 question items, only six items that have no preference, while 16 question items contain bias. Respondents spend 5-10 million from 22 items of question 9 that contain no bias, while 13 items have a preference. It can be concluded that respondents with expenditures under 1 million and respondents with 5-10 million expenses were more comfortable answering questions than other expenditure classifications.

\section{Figure 4 Person DIF Plot (Expense)}

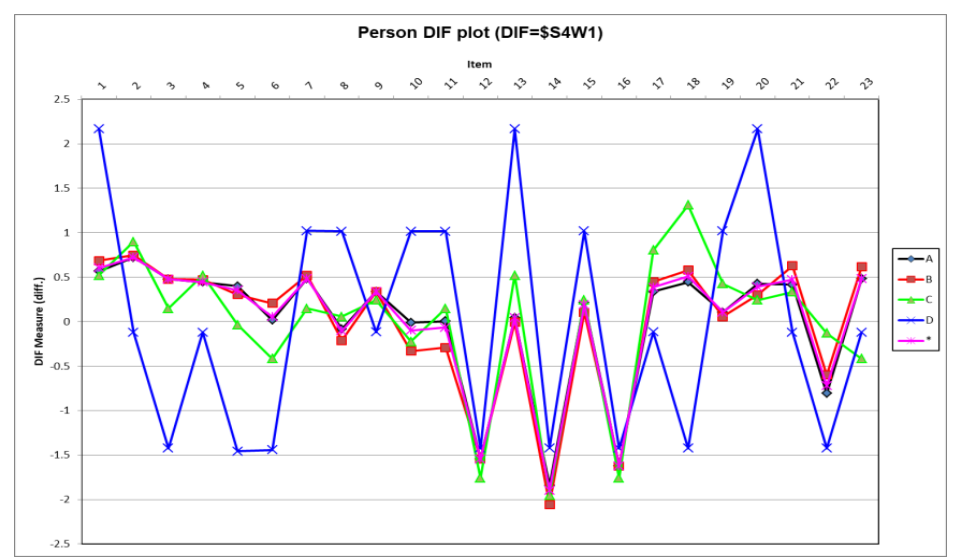

Source: Data Processed (2020) 


\section{Are consumers willing to pay more for products labelled Go Green?}

Based on the frequency analysis, the average value of respondents answering questions is on a scale of 4 , which means that the respondent agrees to pay more for products labelled Go Green. They believe by purchasing environmentally friendly products, and they can contribute to saving the environment. Based on gender, we know that 65 per cent of female respondents in generation $Z$ are more willing to pay more than male respondents.

Based on the Rasch model analysis on the statement item, consumers are willing to pay more for products labelled go green. We know that this item's total score is 1218, with 340 respondents who answered that the measured value is -0.06 with the SE model 0.6. Infit MNSQ 0.98 and ZSTD -0.26 . MNSQ Outfit 0.98 and ZSTD -0.20 . PT Measure Correlation 0.36 and EXP 0.38. Statistically, this statement item is valid. This item is classified as Easier to be agreed upon or considered.

Based on the study's findings, consumers will pay more for products labelled go green if there is proof. Such proofs such as the product's ingredients do not contain harmful components, and the packaging is easily decomposed. According to Kirmani et al. (2018), green marketing is done intensively and highlights that companies sustainably protect the environment.

\section{Discussion}

Generation $Z$ considers statement items classified as greenwashing challenging because they do not believe that companies carry an environmentally friendly label but do not carry out environmentally friendly activities. The statement is consistent with the research of Pires et al. Stated that greenwashing is confusing and influences consumers' trust in green products in retail. The result of the variable mapping, all greenwashing statements items, is in the stratum of problematic statements. According to Walker et al. research, greenwashing harms financial performance (Walker \& Wan, 2012). For green consumers, some companies have a go green logo or promote environmentally friendly good corporate advertising. The company does minor environmental damage but continues to improve the company's performance in anticipating ecological damage. The company utilizes waste and environmentally friendly products. The company realizes that greenwashing can cause losses in the future. Consumers appreciate this transitional change process.

Visual items and misleading wording in company advertising use green advertising; however, the company has not entirely looked after the environment are the most difficult items consumers dislike and are challenging to answer. Consumers do not think the company is lying. They believe there is a process towards better protecting the environment and the earth. Consumers perceive companies that do green advertising better than none at all. The statement follows Nyilasi et al. (2014). However, the results of this study were different from Dahl (Dahl, 2010). Green consumers do not doubt companies that carry environmentally friendly or products labeled go green. They trust the company.

Green consumers protect the environment by not littering. Consumers save on water and energy, consumers who bring their drinking bottles that can be used more than once, so they do not use disposable drinking water bottles, and consumers who like to clean the environment. Consumer awareness of the environment encourages companies in industry and tourism to carry out green practices sustainably. Environmentally friendly labeling activities can be focused primarily on the organic food industry, organic cosmetic products, or agricultural ingredients. It is not surprising that currently, there are technological developments related to this environmentally friendly concept, immaculate and recycled water. Consumers are also willing to pay more for products labeled go green (Fuentes, 2015; Prưša \& Sadílek, 2019).

\section{Conclusion}

From the section above, we can conclude that the most preferred statement items are the statement items that describe the green consumer variable. Thus, it is necessary to increase green marketing communication to know about products labelled green / go green. Consumers are also willing to pay more for products tagged go green. The statement is an advantage for the company in increasing profits and maintaining customer loyalty. Companies need to raise awareness of environmental sustainability and the use of technology aimed at environmental preservation. This study only explains generation Z's response regarding the items contained in the greenwashing and green consumer variables. Future research is expected to use respondents with different 
categories to discover more about consumer behaviour towards green products and responses to green label companies.

Acknowledgement

PNBP Sriwijaya University funded this research.

\section{References}

Arta, G. D., \& Purnami, N. M. (2018). Peran Mediasi Pemasaran Hijau Pada Pengaruh Persepsi Nilai Terhadap Repurchase Intension Pada Garden Villa Seminyak Bali. INOBIS: Jurnal Inovasi Bisnis Dan Manajemen Indonesia, 1(4), 415-422. https://doi.org/10.31842/jurnal-inobis.v1i4.47

Barbulescu, A. (2017). Modeling the impact of the human activity, behavior and decisions on the environment. Marketing and green consumer (Special Issue). Journal of Environmental Management, 204, 813. https://doi.org/10.1016/j.jenvman.2017.10.028

Chae, H., \& Ko, E. (2016). Customer social participation in the social networking services and its impact upon the customer equity of global fashion brands. Journal of Business Research, 69(9), 3804-3812. https://doi.org/10.1016/j.jbusres.2015.12.072

Chan, E. S. W. (2013). Managing green marketing: Hong Kong hotel managers' perspective. International Journal of Hospitality Management, 34(1), 442-461. https://doi.org/10.1016/j.jhm.2012.12.007

Chang, K. C., Hsu, C. L., Hsu, Y. T., \& Chen, M. C. (2019). How green marketing, perceived motives and incentives influence behavioral intentions. Journal of Retailing and Consumer Services, 49(April), 336-345. https://doi.org/10.1016/j.jretconser.2019.04.012

Chen, S. (2016). Selling the environment: Green marketing discourse in China's automobile advertising. Discourse, Context and Media, 12, 11-19. https://doi.org/10.1016/j.dcm.2016.03.003

Cherian, J., \& Jacob, J. (2012). Green marketing: A study of consumers' attitude towards environment friendly products. Asian Social Science, 8(12), 117-126. https://doi.org/10.5539/ass.v8n12p117

Dahl, R. (2010). Green Washing: Do You Know What You Are Buying. Environmental Health Perspectives, 118(6), 246-252.

Fisk, R. P., Grove, S. J., Kangun, N., \& Pickett, G. M. (1996). Going green in the service sector: social responsibility issues, implications and implementation. European Journal of Marketing, 30, 56.

Fuentes, C. (2015). How green marketing works: Practices, materialities, and images. Scandinavian Journal of Management, 31(2), 192-205. https://doi.org/10.1016/j.scaman.2014.11.004

Herbes, C., \& Ramme, I. (2014). Online marketing of green electricity in Germany-A content analysis of providers' websites. Energy Policy, 66, 257-266. https://doi.org/10.1016/j.enpol.2013.10.083

Hong, Z., \& Guo, X. (2019). Green product supply chain contracts considering environmental responsibilities. In Omega (United Kingdom) (Vol. 83). https://doi.org/10.1016/j.omega.2018.02.010

Kao, T. F., \& Du, Y. Z. (2020). A study on the influence of green advertising design and environmental emotion on advertising effect. Journal of Cleaner Production, 242, 118294. https://doi.org/10.1016/j.jclepro.2019.118294

Kirmani, M. D., \& Khan, M. N. (2018). Decoding willingness of Indian consumers to pay a premium on green products. South Asian Journal of Business Studies, 7(1), 73-90. https://doi.org/10.1108/SAJBS-11-20160091

Lai, C. K. M., \& Cheng, E. W. L. (2016). Green purchase behavior of undergraduate students in Hong Kong. Social Science Journal, 53(1), 67-76. https://doi.org/10.1016/j.soscij.2015.11.003

Lim, W. M., Ting, D. H., Bonaventure, V. S., Sendiawan, A. P., \& Tanusina, P. P. (2013). What happens when consumers realise about green washing? A qualitative investigation. International Journal of Global Environmental Issues, 13(1), 14-24. https://doi.org/10.1504/IJGENVI.2013.057323

Majerova, J. (2015). Analysis of Slovak Consumer's Perception of the Green Marketing Activities. Procedia Economics and Finance, 26(15), 553-560. https://doi.org/10.1016/S2212-5671(15)00954-5

Martínez, M. P., Cremasco, C. P., Gabriel Filho, L. R. A., Braga Junior, S. S., Bednaski, A. V., Quevedo-Silva, F., ... Moura-Leite Padgett, R. C. (2020). Fuzzy inference system to study the behavior of the green consumer facing the perception of greenwashing. Journal of Cleaner Production, 242. https://doi.org/10.1016/j.jclepro.2019.03.060

Murin, I., Marková, I., Zelený, J., \& Jad'udová, J. (2015). Green Marketing as a Tool Influencing Consumerś Behavior: Slovak Case Study of Regional Mark Preference. Procedia Economics and Finance, 34(15), 260-267. https://doi.org/10.1016/s2212-5671(15)01628-7 
Nyilasy, G., Gangadharbatla, H., \& Paladino, A. (2014). Perceived Greenwashing: The Interactive Effects of Green Advertising and Corporate Environmental Performance on Consumer Reactions. Journal of Business Ethics, 125(4), 693-707. https://doi.org/10.1007/s10551-013-1944-3

Pires, C., Roberto, L., Gabriel, A., Pag, M., Silva, S., Junior, B., ... Padgett, M. (2019). Fuzzy inference system to study the behavior of the green consumer facing the perception of greenwashing. Journal of Cleaner Production, 242. https://doi.org/10.1016/j.jclepro.2019.03.060

Polonsky, M. J. (2011). Transformative Green Marketing : Impediments and Opportunities. Journal of Business Research, 64(12), 1311-1319.

Průša, P., \& Sadílek, T. (2019). Green Consumer Behavior: The Case of Czech Consumers of Generation Y. Social Marketing Quarterly, 25(4), 243-255. https://doi.org/10.1177/1524500419881783

Punitha, S., \& Mohd Rasdi, R. (2013). Corporate social responsibility: Adoption of green marketing by hotel industry. Asian Social Science, 9(17), 79-93. https://doi.org/10.5539/ass.v9n17p79

Rahayu, L., Abdillah, Y., \& Mawardi, M. (2017). PENGARUH GREEN MARKETING TERHADAP KEPUTUSAN PEMBELIAN KONSUMEN (Survei Pada Konsumen The Body Shop di Indonesia dan di Malaysia). Jurnal Administrasi Bisnis S1 Universitas Brawijaya, 43(1), 121-131.

Rex, E., \& Baumann, H. (2007). Beyond ecolabels: what green marketing can learn from conventional marketing. Journal of Cleaner Production, 15(6), 567-576. https://doi.org/10.1016/j.jclepro.2006.05.013

Rini, A. S., Sukaatmadja, I. P. G., \& Giantari, I. G. A. K. (2017). Pengaruh Pengetahuan Lingkungan Dan Kepedulian Lingkungan Terhadap Sikap Dan Niat Beli Produk Hijau "the Body Shop" Di Kota Denpasar. Bisnis Universitas Udayana, 6(1), 137-166.

Simão, L., \& Lisboa, A. (2017). Green Marketing and Green Brand - The Toyota Case. Procedia Manufacturing, 12(December 2016), 183-194. https://doi.org/10.1016/j.promfg.2017.08.023

Suki, N. M., Suki, N. M., \& Azman, N. S. (2016). Impacts of Corporate Social Responsibility on the Links Between Green Marketing Awareness and Consumer Purchase Intentions. Procedia Economics and Finance, 37(16), 262-268. https://doi.org/10.1016/s2212-5671(16)30123-x

Walker, K., \& Wan, F. (2012). The Harm of Symbolic Actions and Green-Washing: Corporate Actions and Communications on Environmental Performance and Their Financial Implications. Journal of Business Ethics, 109(2), 227-242. https://doi.org/10.1007/s10551-011-1122-4

Widyastuti, S. (2019). Sebuah Sintesisi Pada Literatur: Strategi Intervensi Pemasaran Hijau Menuju Pembangunan Berkelanjutan (A Synthesis of Literature: A Green Marketing Intervention Strategy towards Sustainable Development). JRB-Jurnal Riset Bisnis, 2(2), 83-94. https://doi.org/10.35592/jrb.v2i2.401

Zhang, L., Li, D., Cao, C., \& Huang, S. (2018). The influence of greenwashing perception on green purchasing intentions: The mediating role of green word-of-mouth and moderating role of green concern. Journal of Cleaner Production, 187, 740-750. https://doi.org/10.1016/j.jclepro.2018.03.201

Zhu, Q., \& Sarkis, J. (2016). Green marketing and consumerism as social change in China: Analyzing the literature. International Journal of Production Economics, 181, 289-302. https://doi.org/10.1016/j.jpe.2016.06.006 